\title{
IGNOU's Educational Intervention for the Imprisoned
}

\author{
Bini Toms ${ }^{1, *}$ and V. Venugopal Reddy ${ }^{2}$ \\ ${ }^{1}$ Director I/c, Student Service Centre \\ IGNOU Maidan Garhi \\ New Delhi-110068 \\ ${ }^{2}$ Director, Regional Services Division \\ IGNOU Maidan Garhi \\ New Delhi-110068 \\ *Corresponding author's email: binitoms [AT] ignou.ac.in
}

\begin{abstract}
The Indira Gandhi National Open University (IGNOU), since the past decades, has been making conscious efforts to reach out to the unreached with its diverse, need-based and affordable, Open and Distance learning (ODL) programmes and has been experimenting with various innovative ideas and methods to cater to the diverse needs of its prospective learners. The University, realizing its mandate to reach out to the unreached, ventured into educational intervention behind bars in its attempt to empower this marginalised section of the population. This intervention caters to the learning needs of both literate and semi-literate prisoners and is aimed at reformation of under trials as well as convicted prisoners; all expenditure under this initiative being borne by the University. IGNOU's approach, of imparting education to the imprisoned, falls in line with its vision and mission and with the objectives of democratizing higher education; which is the need of time.
\end{abstract}

This paper details the operationalization aspects and status of this initiative of IGNOU. The paper tries to identify the driving forces behind this noble initiative of the University while discussing on the impact of educational intervention of the imprisoned. The paper while discussing on the special/unique skills needed by educators who act as counsellors for jail inmates, stresses on the need for training of such academic counsellors. As rightly said by Skorton and Altschuler, 2013; "Education, offers a humane and effective alternative to the discipline and punish approach, that all too often breeds only hopelessness and recidivism”.

\section{BACKGROUND}

The Indira Gandhi National Open University (IGNOU), since the past decades, has been making conscious efforts to reach out to the unreached with its diverse, need-based and affordable, Open and Distance learning (ODL) programmes and had been experimenting with various innovative ideas and methods, ultimately to cater to the diverse needs of its prospective learners. Undoubtedly, the university has to a great extent succeeded in attracting a significant group of learners from amongst the underprivileged. However, a considerable cross-section of the underprivileged who are away from the mainstream, like the prisoners, continued to remain beyond reach. The University, realizing its mandate to reach the unreached, ventured into educational intervention behind bars in its attempt to empower this section of the population.

\section{OPERATIONALIZATION}

The operationalization of the above mentioned initiative of Educational Intervention for the Imprisoned is achieved mainly through the following components of the University.

\section{The Regional Services Division (RSD)}

The Regional Services Division (RSD) came into existence in February 1986 to operationalise Student Support Services across the country through a network of Regional Centres and Study Centres. Besides its contribution in policy making and its administrative and financial responsibilities, the RSD has been successfully carrying out its function of negotiating with Government Departments, educational institutions and other voluntary organizations for establishment of new Regional Centres and Study Centres and identifying and appointing suitable coordinators and academic counsellors. 
Each Regional Centre is headed by a Regional Director who is the overall in-charge of activities of the University within the region. The principal responsibilities of the Regional Director are to direct and monitor academic operations and to coordinate the working of the Study Centres. The Regional Director is provided with both academic and nonacademic staff for discharge of academic and administrative responsibilities of the Regional Centre. The staff of the Regional Centre is responsible to the Regional Director and through him to the Director, Regional Services Division. Regular study centre, Programme study centre and special study centre are the types of study centres established under a Regional Centre.

\section{Special Study Centres (SSCs)}

One of the types of study centres is the Special Study Centre (SSC) which is located in an institution/organization, committed to the cause of a certain underprivileged group. The institution/organization should possess the necessary infrastructure facilities and expertise to serve the given group and should be willing to collaborate with IGNOU for delivery of programmes to the disadvantaged by providing rent-free accommodation. Special Study Centres (SSC) are also established in jails for bringing about empowerment through education for the imprisoned.

\section{ESTABLISHMENT OF SSC IN JAILS}

The Regional Director assesses the feasibility for establishing a Special Study Centre in a jail after making visits to the jail and after discussions with the Jail authorities. A proposal in this regard is forwarded by the Regional Director to headquarters which is further examined at the Regional Services Division and the decision about establishment is communicated to the Regional Director. In case of approval, a notification is issued by Regional Services Division regarding establishment of the jail SSC and appointment of Coordinator at the SSC. The Regional Director then executes a Memorandum of Understanding with the jail. Empanelment of part-time Academic Counsellors is undertaken through various Schools of Studies at headquarters.

\section{IGNOU'S EDUCATIONAL INTERVENTION FOR THE IMPRISONED: A DISCUSSION}

IGNOU's initiative of educational intervention of the imprisoned caters to the learning needs of both literate and semi-literate prisoners and is aimed at reformation of under trials as well as convicted prisoners. As mentioned earlier, all expenditure under this initiative is borne by the University.

The jail inmates, who include hardcore Maoists, those awarded capital punishment and lifers, in a number of jails across the country (Table 1) are enrolled in different programmes of the University as evident from Table 1 . While many inmates are enrolled in diploma, graduation and post-graduation programmes as per their qualifications, several others show interest in short term, certificate, vocational and awareness programmes of IGNOU. The University's innovative bachelor preparatory programme (BPP) is offered to those students who wish to pursue bachelors degree of IGNOU but have not cleared their intermediate or equivalent degree.

\begin{tabular}{|c|c|c|c|c|c|c|}
\hline \multirow[t]{2}{*}{ Place/State } & \multirow{2}{*}{$\begin{array}{l}\text { No. of Jail } \\
\text { Study } \\
\text { Centres } \\
(112)\end{array}$} & \multirow[t]{2}{*}{ Regional Centres } & \multirow{2}{*}{$\begin{array}{l}\text { No. of } \\
\text { Jail Study } \\
\text { Centres }\end{array}$} & \multirow{2}{*}{$\begin{array}{l}\text { No. of } \\
\text { Program } \\
\text { mes } \\
\text { Activate } \\
\text { d }\end{array}$} & \multicolumn{2}{|c|}{$\begin{array}{l}\text { No. of } \quad \text { Students } \\
\text { Enrolled }\end{array}$} \\
\hline & & & & & July 2016 & Jan 2017 \\
\hline 1 & 2 & 3 & 4 & 5 & 6 & 7 \\
\hline NORTH & \multicolumn{4}{|c|}{48 Jail Study Centres +8 Sub Centres } & & \\
\hline \multirow[t]{2}{*}{$J \& K$} & \multirow[t]{2}{*}{5} & Jammu & 4 & 11 & 77 & 25 \\
\hline & & Srinagar & 1 & 14 & 25 & 5 \\
\hline HP & 2 & Shimla & 2 & 8 & 53 & Nil \\
\hline Punjab & 6 & Khanna & 3 & 13 & 6 & 1 \\
\hline
\end{tabular}




\begin{tabular}{|c|c|c|c|c|c|c|}
\hline & & Chandigarh & 3 & 26 & 246 & 249 \\
\hline Haryana & 12 & Karnal & 12 & 8 & - & - \\
\hline Uttarakhand & 2 & Dehradun & 2 & 20 & 74 & 11 \\
\hline \multirow[t]{4}{*}{ Delhi NCR } & \multirow{4}{*}{$\begin{array}{ll}6+8 & \text { Sub } \\
\text { Centres } & \end{array}$} & Delhi I & 1 & 5 & 44 & 24 \\
\hline & & Delhi II & 1 & 6 & 112 & 58 \\
\hline & & Delhi III & $\begin{array}{l}1+8 \mathrm{Sub} \\
\text { centres }\end{array}$ & 5 & 308 & 405 \\
\hline & & Noida & 3 & 5 & 2049 & 1079 \\
\hline \multirow[t]{3}{*}{ UP } & \multirow[t]{3}{*}{15} & Lucknow & 10 & 16 & 364 & 688 \\
\hline & & Varanasi & 3 & 21 & 373 & 405 \\
\hline & & Aligarh & 2 & 10 & 199 & 1131 \\
\hline SOUTH & \multicolumn{4}{|c|}{11 Jail Study Centres } & & \\
\hline Karnataka & 1 & Bijapur & 1 & 2 & 45 & 49 \\
\hline \multirow[t]{3}{*}{ Kerala } & \multirow[t]{3}{*}{4} & Trivandrum & 2 & 9 & Nil & Nil \\
\hline & & Cochin & 1 & 2 & 6 & 16 \\
\hline & & Vatakara & 1 & 2 & - & - \\
\hline \multirow[t]{2}{*}{ Tamilnadu } & \multirow[t]{2}{*}{6} & Chennai & 3 & 10 & 31 & 95 \\
\hline & & Madurai & 3 & 19 & 60 & 56 \\
\hline EAST & \multicolumn{4}{|c|}{24 Jail Study Centres } & & \\
\hline \multirow[t]{3}{*}{ Bihar } & \multirow[t]{3}{*}{6} & Patna & 1 & 13 & Nil & Nil \\
\hline & & Saharsa & 2 & 5 & Nil & Nil \\
\hline & & Bhagalpur & 3 & 6 & 10 & 56 \\
\hline \multirow[t]{2}{*}{ Jharkhand } & \multirow[t]{2}{*}{3} & Ranchi & 1 & 4 & 50 & 19 \\
\hline & & Deoghar & 2 & 5 & 164 & 118 \\
\hline Chattisgarh & 8 & Raipur & 8 & 5 & 554 & 298 \\
\hline \multirow[t]{2}{*}{ Odisha } & \multirow[t]{2}{*}{6} & Bhubaneshwar & 4 & 8 & 175 & 156 \\
\hline & & Koraput & 2 & 4 & 10 & 18 \\
\hline $\begin{array}{ll}\text { Andaman } & \& \\
\text { Nicobar Islands } & \end{array}$ & 1 & Port Blair & 1 & 5 & Nil & Nil \\
\hline
\end{tabular}




\begin{tabular}{|c|c|c|c|c|c|c|}
\hline NORTH EAST & \multicolumn{4}{|c|}{4 Jail Study Centres } & & \\
\hline Manipur & 1 & Imphal & 1 & 3 & 9 & 21 \\
\hline Mizoram & 1 & Aizawl & 1 & 6 & 10 & 19 \\
\hline Assam & 1 & Guwahati & 1 & 7 & - & - \\
\hline Meghalaya & 1 & \begin{tabular}{|l|} 
Shillong \\
\end{tabular} & 1 & 2 & 1 & Nil \\
\hline WEST & \multicolumn{4}{|c|}{51 Jail Study Centres } & & \\
\hline \multirow[t]{2}{*}{ Gujarat } & \multirow[t]{2}{*}{17} & Ahmedabad & 10 & 16 & 7234 & 4142 \\
\hline & & Rajkot & 7 & 3 & 180 & 139 \\
\hline \multirow[t]{2}{*}{ MP } & \multirow[t]{2}{*}{14} & Bhopal & 5 & 16 & 576 & 504 \\
\hline & & \begin{tabular}{|l|} 
Jabalpur \\
\end{tabular} & 9 & 14 & 404 & 313 \\
\hline \multirow[t]{2}{*}{ Rajasthan } & \multirow[t]{2}{*}{13} & Jodhpur & 3 & 18 & 390 & 340 \\
\hline & & Jaipur & 10 & 23 & 675 & 514 \\
\hline \multirow[t]{3}{*}{ Maharashtra } & \multirow[t]{3}{*}{6} & Nagpur & 2 & 3 & 64 & 73 \\
\hline & & Mumbai & 1 & 1 & 86 & 98 \\
\hline & & Pune & 3 & 10 & 60 & 70 \\
\hline Goa & 1 & Panaji & 1 & 3 & 12 & 11 \\
\hline
\end{tabular}

Table 1: A GLANCE AT IGNOU'S INTERVENTION IN JAILS

A perusal of Table 1 reveals that in all, 146 jails across the country have been involved in this massive educational intervention. This figure includes 48 Jail Study Centres in the north, 11 in the south, 24 in the east, 4 in the north east and 51 in the western region of the country. The maximum number of Jail Study Centres have been activated in the state of Gujarat (17) followed by Uttar Pradesh (15), Madhya Pradesh (14), Rajasthan (13) and Haryana (12). The number of programmes activated at these Jail Study Centres functioning from various Regional Centres is as high as 26 under RC Chandigarh closely followed by RC Jaipur (23) and RC Varanasi (21) as shown in the table. The table also shows huge enrolment of jail inmates at several centres indicating that the efforts made by the University in this direction were indeed need based and not futile. There are several encouraging case studies and success stories from different jail study centres across the country. Continuous and consistent efforts are made by the Regional Centres to reach out to more and more jails across the length and breadth of the country to facilitate this section of the population with education.

The main driving forces and reasons behind the university taking up such a noble initiative are the following:

1. Ethical reason

2. Social reasons

- Correctional education

- Reduction in recidivism

3. Personal development

4. Resonance with the vision and mission of IGNOU 
5. Consonance with the concept of ODL

\section{Ethical reason}

Ethically speaking, the act of wrong doing in any way violates the moral code of behaviour but it is important to consider the possibility that the concerned person must have been in a disturbed mental state to have done the act. If the person was indeed in a disturbed state of mind, then he/she needs help, more than punishment. In such a case, the society has an ethical and moral duty to ensure the same. Correctional education as explained in the next section could help such people in healing their wounds and help them in repairing the harm done to interpersonal relationships and the community (restorative justice). Restorative justice is concerned with restoring offenders to law-abiding lives. Restorative justice would strengthen them and thus prevent them from doing wrong in future (Maiese, 2003). Since there is a human tendency to slip to revenge taking mindset when subject to punitive justice (punishment for wrong-doing); restorative justice processes may be more effective.

2. Social reasons: can be described under two heads viz.,

- Correctional education

- Reduction in recidivism

Educational intervention in prisons is correctional education aiming at reduction in recidivism and promoting social integration of the prisoners.

\section{Correctional education}

Interaction of our Regional Directors and study centre coordinators with prisoners have revealed their conviction that education can empower them, bring them into the mainstream and help them lead a normal life when they come out of the prison with a degree from a reputed university. Many of the prisoners are determined to use the opportunity created by IGNOU to make better lives for themselves and their families.

Similar experiments of education behind bars, carried out in different parts of the world have yielded successful results. An American study found that one million dollars spent on correctional education prevents about 600 crimes, while that same money invested in imprisonment/confinement prevents 350 crimes. According to Bozos and Hausman, 2004; correctional education is almost twice as cost-effective as a crime control policy. With good skills and an education, released prisoners can overcome prison record in a better way. $75 \%$ of college-educated ex-prisoners are able to surmount the stigma of their criminal record to find stable employment (Erisman and Contardo, 2005).

\section{Reduction in recidivism}

Experience of educational intervention by IGNOU over the years has shown that prison education has successfully reduced the recidivism rate for released prisoners. Similar studies in the US have shown that the rate of recidivism within three years of release was found to be between $43.3 \%$ and $51.8 \%$ (Langan and Levin, 2002). Those released prisoners who received an education had a significantly lower rate of recidivism (Burke and Vivian, 2001; Harer, 1995; Haulard, 2001; Porporino and Robinson, 1992; Ryan, 1991).

\section{Personal development}

To the under-privileged prisoners, who are in a way privileged to get the opportunity to further their education, this noble initiative of IGNOU is indeed a glimmer of hope. As pointed out by Erisman and Contardo, 2005 in their study, for many jail inmates this positive intervention creates a hope that they can escape the cycles of poverty and violence that have dominated their lives. Education increases their self-reliance and employability. Pursuing an education can also undo some of the damage accrued during their stay in prison; it can awaken senses numbed and release creativity that is both therapeutic and rehabilitative (Piche, 2008). This personal development helps the exprisoners get out of prison and stay out. Interaction with few female prisoners who are IGNOU students have revealed that before enrolling with IGNOU, they used to spend time gossiping and sleeping after finishing their assigned tasks, but now they had something to look forward to- knowledge, skill, a certificate and dreams- for a livelihood once released. 


\section{Resonance with the vision and mission of IGNOU}

IGNOU's approach, of imparting education to the imprisoned, falls in line with its vision and mission and with the objectives of democratizing higher education; which is the need of time. According to Pelletier, 2011, "Democratization of higher education" is a rather amorphous phrase, under which one can park all kinds of political and economic considerations. However, in this paper, the focus is on one central dimension of the concept of democratization, i.e., access to higher education.

Providing free and compulsory education to all children is a goal that is enshrined in the Indian Constitution as a Fundamental Right. This, indeed, is also the focus of the World Declaration on 'Education for All', adopted nearly 25 years ago. The World Education Forum, held in 2000, reiterated the commitment. Following this commitment, India prepared a National Plan of Education 2002, delineating various programmes and strategies for achieving various Education for All (EFA) Goals and the RTE Act in 2009 (Govinda, 2014). The initiatives of IGNOU to impart education to anybody, anywhere, anytime, using all channels is in accordance with these documents. As India strives to become a knowledge society, IGNOU ensures that no section gets left behind. In addition, in a situation when there is growing demand of skilled workforce in our country and across the globe, IGNOU's intervention in prisons contributes towards meeting this demand too.

\section{Consonance with the concept of $O D L$}

One of the facts that make IGNOU's initiative in this regard different from others is that educational intervention is made in the Open and Distance Learning (ODL) mode. The vision statement of the Indira Gandhi National Open University describes it as the National Resource Centre for ODL. Besides providing an overview of the University's SSC in jails, this paper also highlights the suitability of the idea of openness and distance learning for education of the imprisoned. The convenience of time and space is a big promise made by distance learning. Students do not have to physically be with the instructor in space and depending on the method used, they do not have to be together in time either which is a great advantage for non-traditional students like prisoners.

The concept of lifelong learning is central to openness. The concept draws upon the fact that learning should continue throughout life, rather than being limited to a certain age and should have direct bearing on the needs and life experiences of all kinds of learners, be it even the underprivileged like prisoners. The concept of lifelong learning is not, merely a philosophical concept about human rights, but a national necessity for economic survival (Cropley, 1980).

\section{SKILLED ACADEMIC COUNSELLORS FOR SERVING IN PRISONS}

Prison inmates lodged in Indian jails are categorized as convicts, under-trials and detenues. A convict is "a person found guilty of a crime and sentenced by a court" or "a person serving a sentence in prison". An under-trial is a person who is currently on trial in a court of law. A detenue is any person held in custody. When discussing educational intervention in prisons, it is important to remember that all these categories with different mind sets and short term objectives co-exist in prisons. Another aspect is the education level of jail inmates. According to the Hindu, the educational profile of convicts in Indian jails in 2015 was as follows:

$\begin{array}{lc}\text { Illiterate } & 36,406 \\ \text { Below Class X } & 57,610 \\ \text { Above but below graduation } & 28,941 \\ \text { Graduate } & 7,167 \\ \text { Post Graduate } & 2,460 \\ \text { Degree/Diploma } & 1,584\end{array}$

Tech. Degree/Diploma $\quad 1,584$

When we visualize Indian prisons, another facet is, overcrowding. The Shah Commission reports that in many cases, the actual population of prisoners far exceeded the authorized accommodation. In Assam there were 7909 
prisoners in accommodation meant for 4,930; Bihar- 38,407 as against 21,140; Madhya Pradesh-16,66 as against 12,388; Orissa-10,222 as against 6,668; Maha-rashtra-19,786 as against 14,801; West Bengal-25,999 as against 20,237; Delhi 2,699 as against 1,273 (Nanda, 1981). The other problems in jails include, retributive rather than reformative approach, ill treatment of prisoners demanding better treatment for themselves, rampant corruption in jail administration, low wage scale of jail staff, lack of resources for jail administration, hopeless conditions in jails, victimization of the poor and the innocent and so on. Looking at the conditions in jails, educational development of inmates is a challenge and there is a need for academic counsellors with unique skills for imparting education in jails. Further, looking at the category of jail inmates and their educational profile and realizing that the learners in jails range from school drop outs, hard core criminals to intellectuals, doctors and politicians; there is a need to engage academic counsellors with special skills for teaching in jails. Teachers in jails should have unique qualities and skills like being positive, accommodating, supportive, altruistic, bold, realistic, making regular self assessment, promoting mutual respect and having good classroom management skills. They should be able to deal with different kinds of prisoners on a case to case basis and not as per general standards. Besides, they should be convinced of the idea of correctional and reformative education. Regardless of where they work, effective teachers remain true to their overall goal: to offer an outstanding education to all students whom they have the privilege of teaching (Benard, 2004; Thompson, 2010). In view of the reasons detailed, IGNOU plans to conduct well planned, systematic training programmes on a regular basis for those teachers (academic counsellors) who have been identified for jails.

\section{CONCLUSION}

As rightly said by Skorton and Altschuler, 2013; "Education, offers a humane and effective alternative to the discipline and punish approach, that all too often breeds only hopelessness and recidivism". With a passion to reach the unreached and democratise higher education, in general, and with a robust mechanism to educate the imprisoned through jail SSCs in particular, this dynamic and innovative university IGNOU, has indeed become the People's University today.

\section{REFERENCES}

1. Benard, B. 2004. "Resiliency: What we have learned". San Francisco, CA: WestEd.

2. Bozos Audrey and Hausman Jessica., 2004. "Correctional Education as a Crime Control Program; UCLA School of Public Policy and Social Research", Department of Policy Studies (March 2004) pp:2.

3. Burke, L.O. and Vivian, J.E., 2001. "The Effect of College Programming on Recidivism Rates at the Hampden County House of Correction: A 5-Year Study"; Journal of Correctional Education, Vol. 52, No. 5 (2001) pp: $160-162$.

4. Cropley, A.J., 1980. "Lifelong Learning and Systems of Education An Overview", in Towards a System of Lifelong Education, Cropley, A.J. (Ed), Oxford, UNESCO Institute for Education \& Pergamon Press, pp: 2.

5. Erisman, W. and Contardo, J. B., 2005. "Learning to reduce recidivism: A 50-state analysis of postsecondary correctional education policy". Washington, DC: Institute for Higher Education Policy.

6. Govinda R., 2014, in Education for All Towards Quality with Equity India First Edition August 2014 National University of Educational Planning and Administration (NUEPA), New Delhi; Declared by the Government of India, under Section 3 of the UGC Act, 1956.

7. Harer, M.D., 1995. "Recidivism Among Federal Prisoners" Released in 1987, Journal of Correctional Education, Vol. 46, No. 3 (1995) pp:98-128.

8. Haulard, E.R., 2001. "Adult Education: A Must for Our Incarcerated Population”, Journal of Correctional Education, Vol. 52, No. 4 (2001) pp:157-159.

9. IGNOU Student Handbook and Prospectus, 2012, New Delhi, IGNOU.

10. IGNOU, 2009. Celebrating $25^{\text {th }}$ Year of Success in Open \& Distance Learning 2009-2010, Vol. 1 , Issue 1.

11. IGNOU website, www.ignou.ac.in

12. Langan Patrick A. and Levin David J., 2002. "Recidivism of Prisoners" Released in 1994, U.S. Department of Justice, Bureau of Justice Statistics (2002).

13. Maiese Michelle., 2003. “Types of Justice. Beyond Intractability”. Eds. Guy Burgess and Heidi Burgess. Conflict Research Consortium, University of Colorado, Boulder. Posted: July 2003 <http://www.beyondintractability.org/essay/types_of_justice/>.

14. Nanda Raman., 1981. "Jails in India : An Investigation”, PUCL Bulletin, Nov 1981, http://www.pucl.org/fromarchives/81nov/jails.htm. 
15. Pelletier, Stephen G., 2011. "Education for all Public institutions who are leaders in the democratization of higher education"; on 50 th anniversary Fall 2011. Media and Publications /Public Purpose Magazines/ www.aascu.org.

16. Piche, J., 2008. "Barriers to Knowledge Inside: Education in Prisons and Education on Prisons", Journal of Prisoners on Prisons, Vol. 17, No. 1 (2008) p. 10.

17. Porporino, F.J. and Robinson, D., 1992. "Can Educating Adult Offenders Counteract Recidivism?” Correctional Services of Canada, Research Branch (1992).

18. Ryan, T.A., 1991. "Literacy Training and Reintegration of Offenders", Journal of Correctional Education, Vol. 3, No. 1 (1991) pp:1-13.

19. Skorton David and Altschuler Glenn., 2013. "College Behind Bars: How Educating Prisoners Pays Off”; Education 3/25/2013 @ 5:43AM.

20. Thompson, G. 2010. "The power of one: How you can help or harm African American students". Thousand Oaks, CA: Corwin. 